Aeromagnetic measurements in the Cascade Range and Modoc Plateau of northern California -- Report on work done from June 1, 1980, to November 30,1980

By Richard Couch and Michael Gemperle

Oregon State University

Corvallis, Oregon 97331

Open-File Report 32-932

This report was prepared under Grant No. 14-08-0001-G-623 from the U.S. Geological Survey and has not been reviewed for conformity with USGS editorial standards and stratigraphic nomenclature. Opinions and conclusions expressed herein do not necessarily represent those of the USGS. Any use of trade names is for descriptive purposes only and does not imply enciorsement; by the USGS.

\title{
Project Information
}

This report was prepared under Grant No. 14-08-0001-G-623 to Oregon State University from the U.S. Geological Survey's Geothermal Research Program, with Dr. Richard Couch of the School of Oceanography as the Principal Investigator. The period of the grant was from June 1, 1979, to October 31, 1981. Objectives of the grant were as follows: (1) To obtain high-quality aeromagnetic data over a 30,000-square-kilometer area in the Cascades and Modoc Plateau of northern California and (2) to analyze the data in terms of structure, volcanic centers, regional trends, Curie-temperature isotherm depths, and the implications concerning the geotinermal energy potential of the area. The data obtained during tine course of this project and described in this report are on file in the National Geophysical Data Center (NGDC) of NOAA in Boulder, CO.

\section{NOTICE}

PORTIONS OF THIS REPORT ARE ILLEISIBLE.

It has been reproduced from the best available copy to permit the broadest possible availability.

OSTRBMIN" OF IHIS OOCOMENT IS UNLIMITED

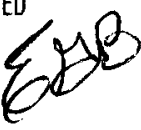




\section{DISCLAIMER}

This report was prepared as an account of work sponsored by an agency of the United States Government. Neither the United States Government nor any agency Thereof, nor any of their employees, makes any warranty, express or implied, or assumes any legal liability or responsibility for the accuracy, completeness, or usefulness of any information, apparatus, product, or process disclosed, or represents that its use would not infringe privately owned rights. Reference herein to any specific commercial product, process, or service by trade name, trademark, manufacturer, or otherwise does not necessarily constitute or imply its endorsement, recommendation, or favoring by the United States Government or any agency thereof. The views and opinions of authors expressed herein do not necessarily state or reflect those of the United States Government or any agency thereof. 


\section{DISCLAIMER}

Portions of this document may be illegible in electronic image products. Images are produced from the best available original document. 


\section{CONTENTS}

Abstract...................................

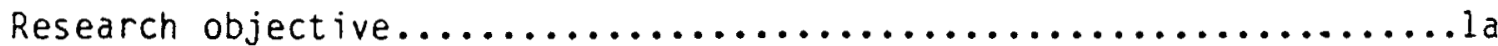

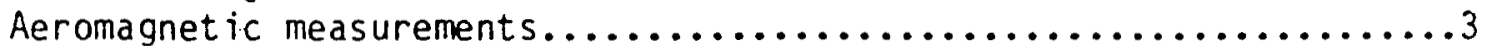

Data processing and magnetic-anomaly map preparation..............

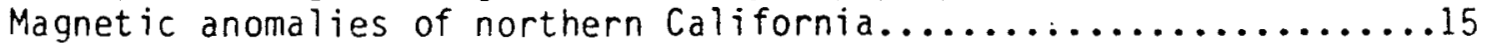

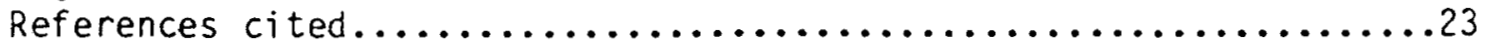

\section{FIGURES}

Figure 1 Northern california geological provinces and

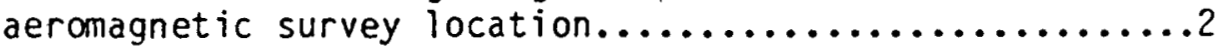

Figure 2 Northern $\mathrm{Ca}$ lifornia aeromagnetic flightlines..........4

Figure 3 Lassen Peak aeromagnetic flightlines...............5

Figure 4 Mt. Shasta aeromagnetic flightlines..............6

Figure 5 Graph of 2885 crossing errors calculated for the northern California 9,000-foot ASL aeromagnetic

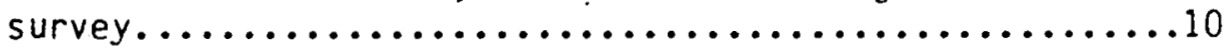

Figure $6 \quad$ Graph of 191 crossing errors calculated for Lassen

Peak 11,000-foot ASL aeromagnetic survey............11

Figure 7 Graph of 44 crossing errors calculated for the Mt. Shasta 15,000-foot ASL aeromagnetic survey........12

Figure 8 . Topographic map of northern California..............

Figure 9 Total-field magnetic-anomaly map of northern

California...................................

Figure 10 Total-field magnetic-anomaly map of Lassen Peak........19

Figure 11 Total-field magnetic-anomaly map of Mt. Shasta.......20

\section{TABLES}

Table 1 Northern California 9,000-foot ASL survey

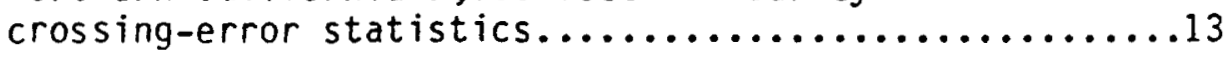

Table 2 Northern California 11,000-foot ASL survey

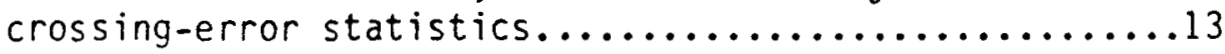

Table 3 Northern California 15,000-foot ASL survey crossing-error statistics....................... 
Abstract

Aeromagnetic measurements made along flightlines oriented eastwest and spaced at $1.6-\mathrm{km}$ intervals and along lines oriented northsouth and spaced at $8-\mathrm{km}$ intervals, over approximately 30,000 square $\mathrm{km}$ of northern California, exhibit.crossing errors of less than 5. nanotesias. The. measurements show short-wavelength magnetic anomalies associated with near-surface volcanics over and east of Lassen Peak and over and north of Mt. Shasta and the Medicine Lake Highlands, longer wavelength anomalies over the Modoc Plateau, and very iong wavelength anomaites over the northernmost part of the Great Valley and the easternmost metamorphic rocks of the Klamath Mountains. Anomaly patterns exhibit northwest-southeast trends over the Modoc Plateau and a marked change in character at the juncture of the plateau and the Klamath Mountain and Great Valley complexes. 


\section{Reseärch Objective}

Figure 1 outlines an area of approximately 30,000 square kilometers that extends from the Oregon-California border at $42^{\circ} \mathrm{N}$. latitude to south of Lassen Pk. at $40^{\circ} 75^{\prime} \mathrm{N}$. latitude and approximately between $121^{\circ} 45^{\prime}$ and $122^{\circ} 45^{\prime} \mathrm{W}$. Tongitude. This area encompasses the southern Cascade Mountain Range, the adjoining Modoc Plateau including the Medicine Lake Highlands, and the northern terminus of the Great Valley, and the easternmost flank of the Klamath Mountains. The objectives of this study are: to obtain precise aeromagnetic measurements in the region; to delineate the mangtic anomalies associated with the cascade Range and the transition region between the Cascade Range and the basin and range structures east of the Cascades; to determine the depths to the magnetic sources; and to estimate the depths of the Curie-point . isotherm in the region. These analyses will assist in the geologic and tectonic interpretation of the region and provide data to help assess the geothermal resource potential of the region. This report describes the location and accuracy of the aeromanetic measurements, and briefly describes the observed total-field magnetic anomalies. 


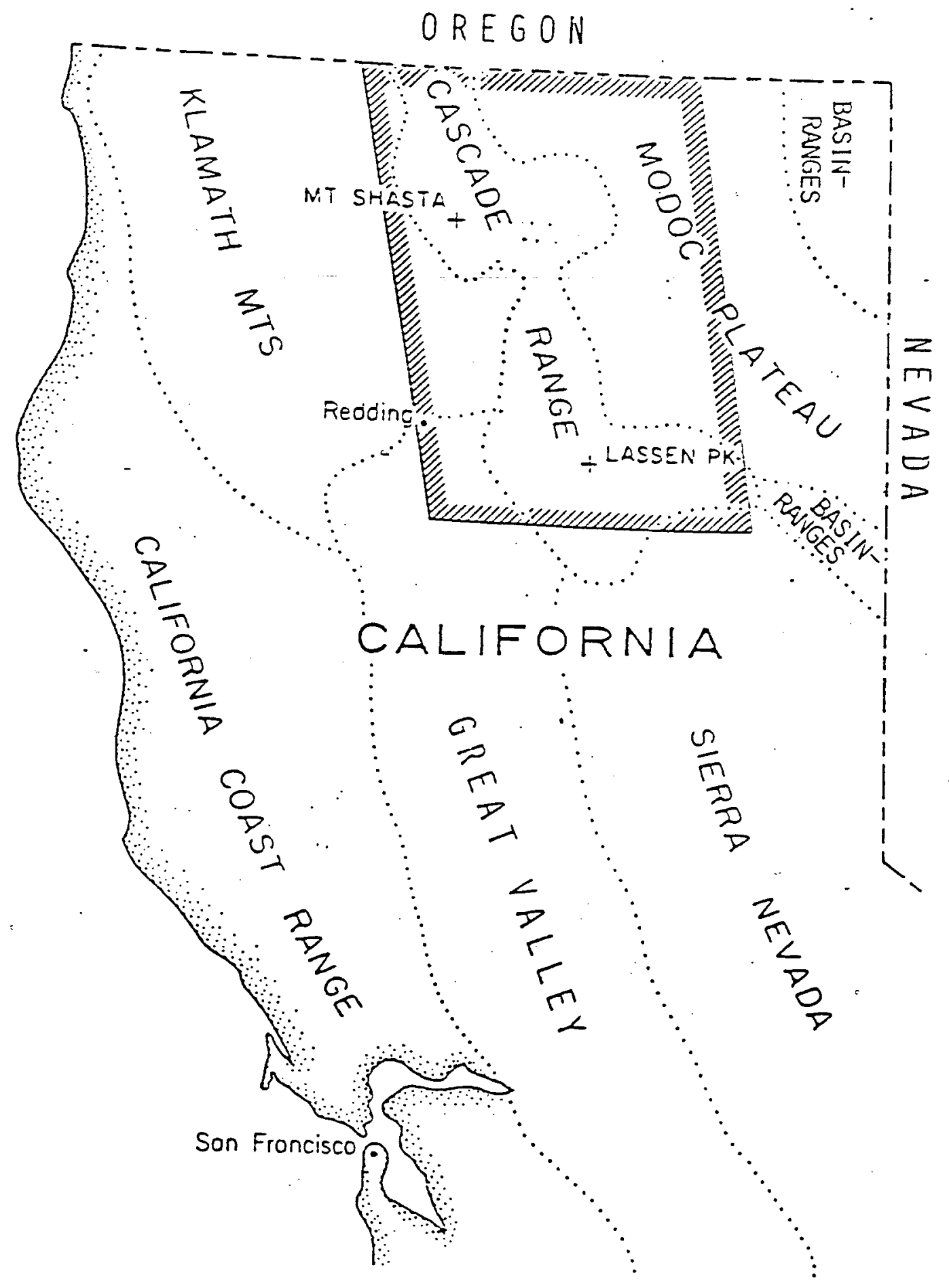

Figure 1. ivorthern California physiographic provinces and
aeronagnetic survey location (out lined by shading). 


\section{Aeromagnetic Measurements}

During June, July, and August 1980, magnetic measurements were made over northern California in the area between $40^{\circ} 15^{\prime}$ and $42^{\circ} \mathrm{N}$. latitude and $120^{\circ} 45^{\prime}$ and $122^{\circ} 45^{\prime} \mathrm{W}$. longitude. Figure 1 outlines the aeromagnetic survey area, and figures 2,3 , and 4 show the flight 7 ines along which over $25,000 \mathrm{~km}$ of aeromagnetic data were obtained. The measurements were made with a twin-engined Piper Aztec aircraft flying at approximately $240 \mathrm{~km} / \mathrm{hr}(150 \mathrm{mph})$. A 2-second data sample rate yielded a data point spacing, along the flight lines, of approximately 130 meters. The survey yielded over 200,000 measurement:. of the Earth's magnetic field at accurately located positions.

Figure 3 sho:/s tine flightlines at 2,740 meters $(9,000$ feet) altitude above sea level (ASL) over the survey area. East-west lines spaced at 1 -mile $(1.6-\mathrm{km})$ intervals and north-south lines spaced at 5 -mile (8. - $\mathrm{km})$ intervais were flown over the entire area. In addition, 0.5$m i l \in(0.8-\mathrm{km})$ spaced east-west lines were flown over the Medicine Lake Highlands east of Mt. Shasta and in the Lassen Peak area in the southern part of the survey area. East-west lines spaced $0.5 \mathrm{mile}(0.8 \mathrm{~km})$ apart were also flown over the summit area of Lassen Peak at 3;353 meters $(11,000$ feet) altitude. Figure 3 shows these lines. Figure 4 shows lines flown at 4,527 meters $(15,000$ feet) over the summit of Mt. Shasta. These lines were spaced 0.5 mile $(0.8 \mathrm{~km})$ apart. The higher density of data in these areas of current interest should allow for a more detailed analysis of these areas in future studies. 


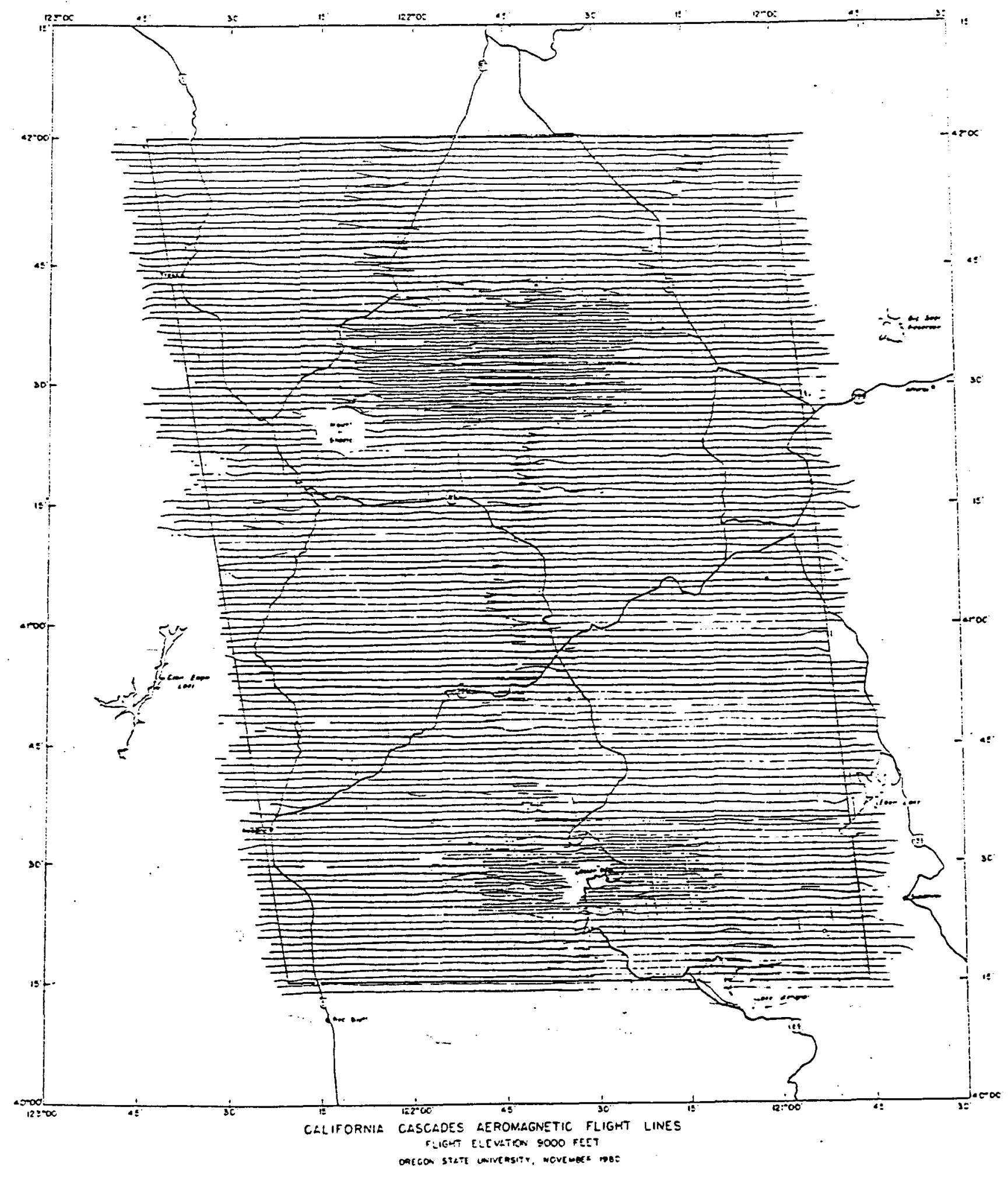

Figure 2 


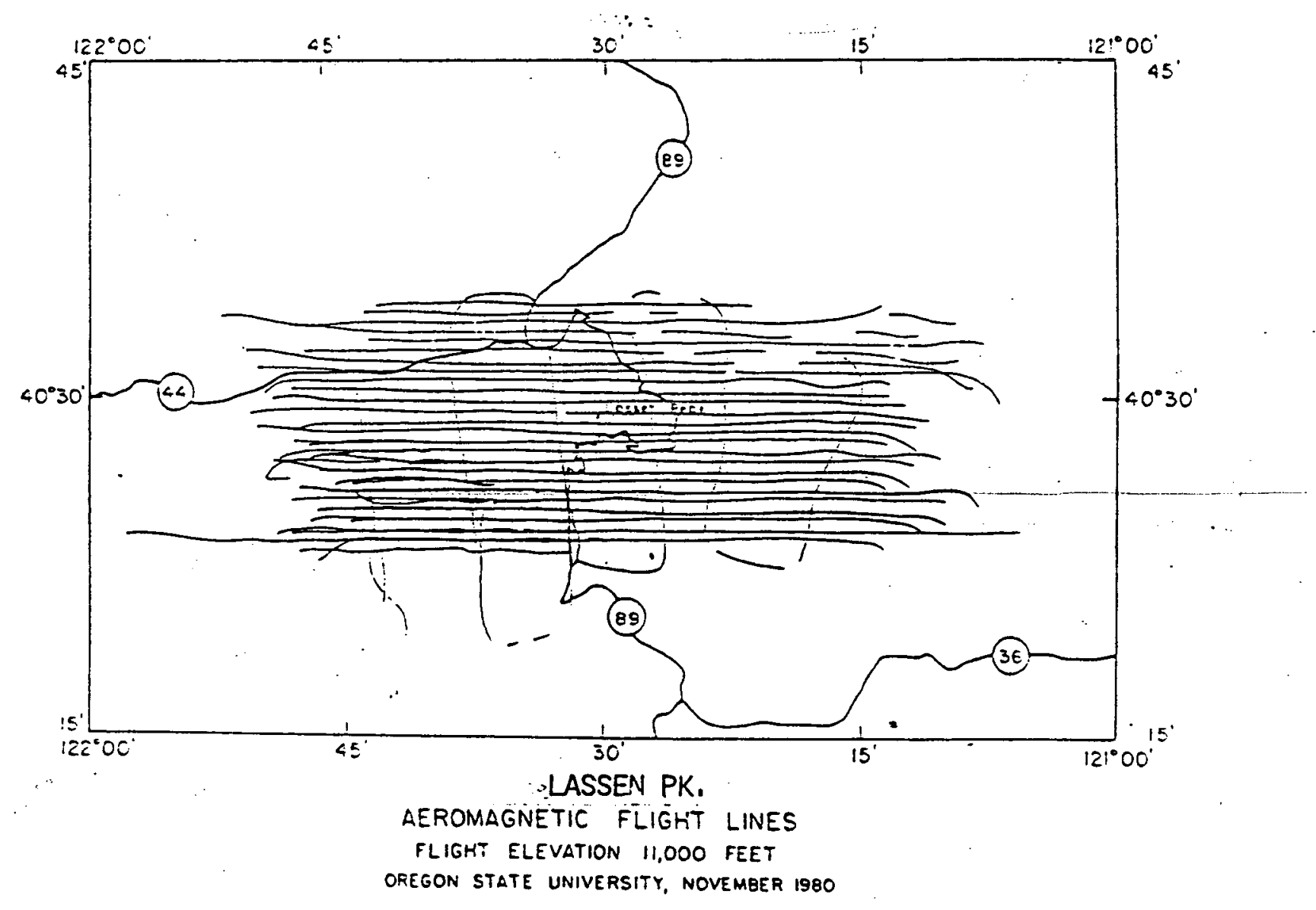

Figure 3. 


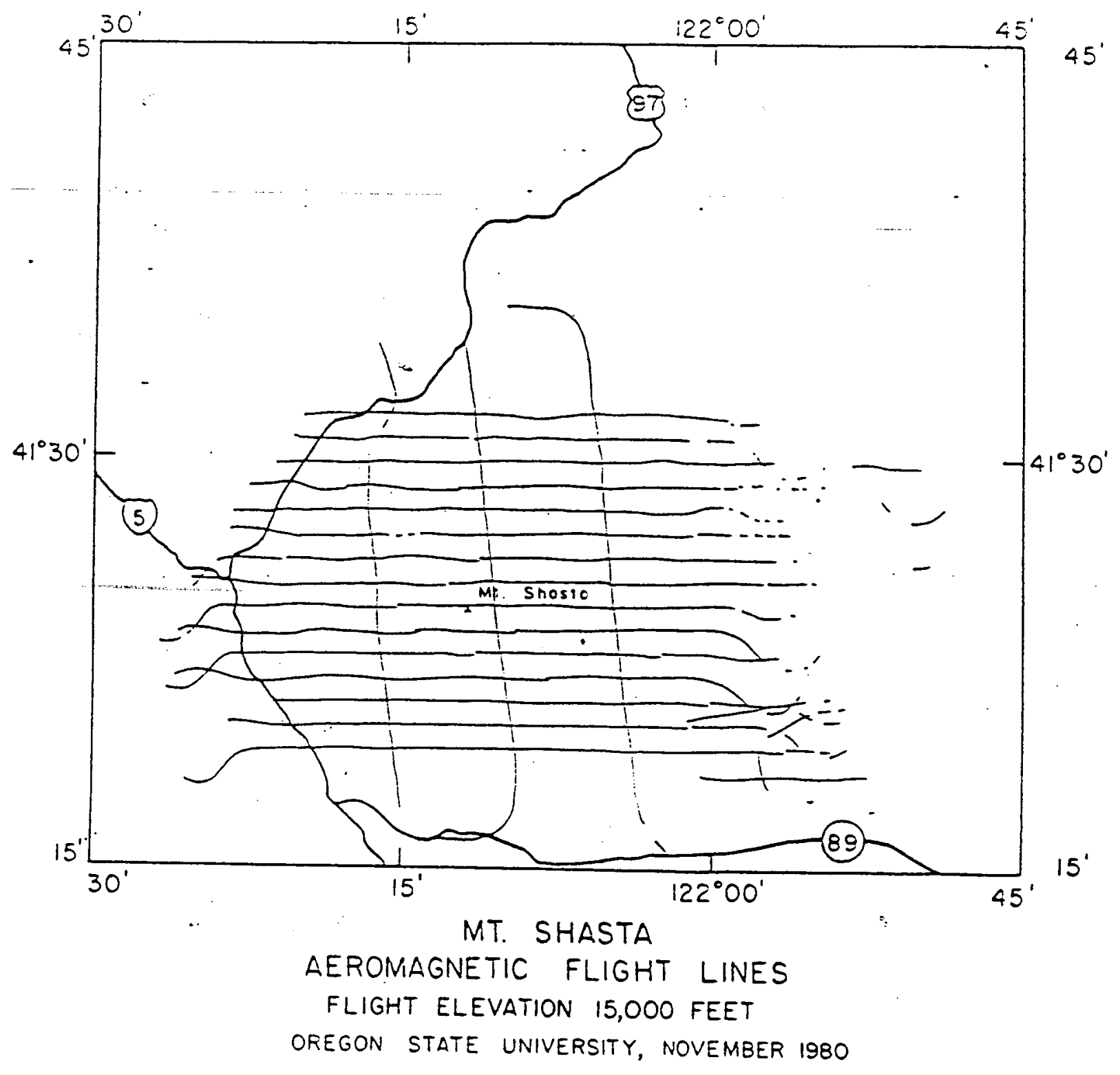

Figure 4. 
Data Processing and Magnetic-Anomaly-Map Preparation

Field processing of the aircraft acquisition system data consisted of reading and checking the field tapes for data errors, converting altitudes to feet and filling in any missing altitude data by linear interpolition, and making plots of magnetic measurements and radar pressure altimeter. readings. Field processing of base station data included checks for time-sequence or data errors, plots of magnetic and pressure altitude variations, ar.: smoothing both altitude and magnetic data with a five-point moving average filter. The filtered base-station data supplied diurnal pressure altitude and magnetic variation corrections for the flight data. The magnetic and altimetric data from each flight were plotted in profile form to further check for errors. Fidally the base reference value of 53,713 nanoteslas $(n \pi$ ) was subtracted from each magnetic reading to form a diurnal variation correction for the magnetic measurements taken in the aircraft. Subsequently all the data were processed țo make the data tapes compatible with the Eclipse system at Oregon State University (OSU).

At OSU the aircraft data and base-station data from each flight were merged. The navigation ranges were converted to State Plane Coordinates (California North zone) and subsequently to latitude and longitude for each magnetic reading. Data points missing navigation points were located by interpolation. Finally, magnetic-anomaly values 
were calculated, using the equation:

$$
A(x, y)=M_{1}(x, y, t)-D(t)-R(x, y)
$$

where $A$ is the anomaly value, $M_{i}$ is the measured value of the total magnetic fieio at time $t$, $D$ is the diurnal variation at time $t$,. and $R$ is the regional magnetic field. The regional magnetic field $R$ was determined from the international Geomagnetic Reference field of 1975 (International Association of Geomagnetism and Aeronomy, 1976) updiated to the survey time and then modified to allow animaly values in this survey to match anomaly values in the survey adjacent to the northern boundary (MCLain, 1981; R: Couch and M. Gemperle, 1981, unpub. data).

The following equations give the regional field values in $\mathrm{nf}$ used in this survey:

$$
\begin{aligned}
& \text { Regional } \begin{aligned}
&(9000 \mathrm{ft} \text { ASL })=50,166.083 \div(1.03900598 \times \\
&\left.10^{-3}\right)(\mathrm{x})-\left(0.473232 \times 10^{-10}\right)\left(x^{2}\right) \div \\
&\left(1.57310835 \times 10^{-3}\right)(y)- \\
&\left(0.575790 \times 10^{-10}\right)\left(y^{2}\right) \\
& \text { Regional }(11000 \mathrm{ft} \mathrm{ASL})=50,394.592+\left(0.830215 \times 10^{-3}\right)(x) \\
&+\left(1.52514 \times 10^{-3}\right)(y)
\end{aligned} \\
& \text { Regional }(15000 \mathrm{ft} \mathrm{ASL})=50,338.478+\left(0.855628 \times 10^{-3}\right)(x) \\
& +\left(1.47816 \times 10^{-3}\right)(y)
\end{aligned}
$$

where $x$ and $y$ are in State Plane coordinates. 
A simple statistical analys is of the differences at survey - (root mean square)

flightline crossings yielded an estimite of the Rlis uncericinty oi the final magnetic-anomaly values. Figures 5, 6, and 7 each:show a graph of the crossing errors for the 9000 ; 11000-and $15000-f t$ ASL surveys, respectively. Tabies 1,2 , and 3 list the corresponding statistics. The RMS uncertainty per line attributes one-hali of the mistie to each of the ilightiones used in calculating the uncertainty, i.e.,

RMS uncertainty per line = RMS mistie/ $\sqrt{2}$.

- The RMS uncertainties per line for these surveys are $4.7,4.0$, and 1.3 nT, respectively. These low values reflect the excelient navigation control and the careful monitoring of the diurnal changes. Estimates of the components of the uncertainty are:

$1 n \pi$ resclution of the airbornemagnetometer

- In resolution of the base-station magnetometer

1-2nT diurnal correction

$1-2 n i \quad x-y$ position determination in low-gradient areas

1-2nT 2 position determination in low-gradient areas. 


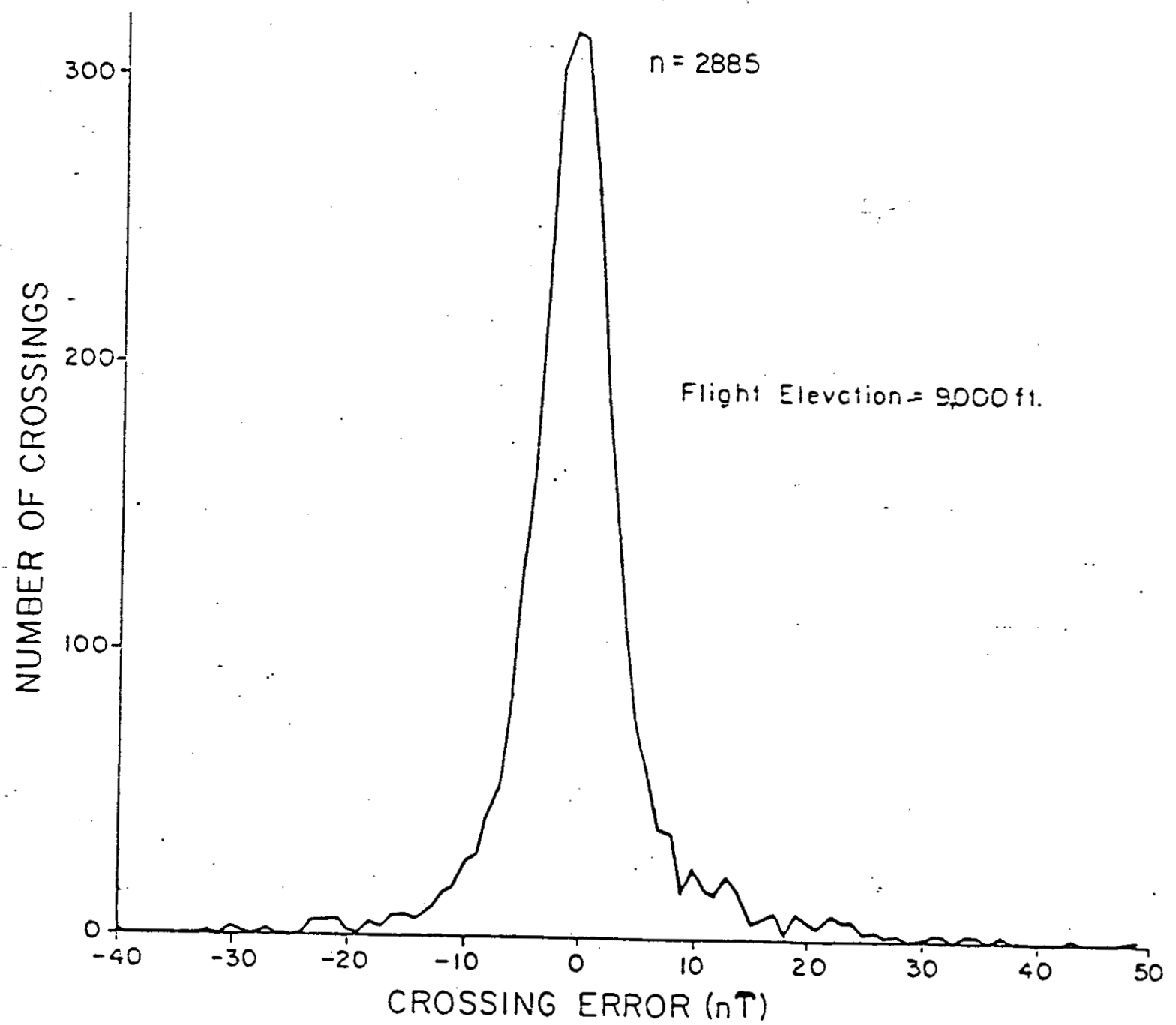

Figure 5.

Graph of 2,885 crossing errors calculated for the northern California 9,000-foot ASL aeromagnetic survey. 


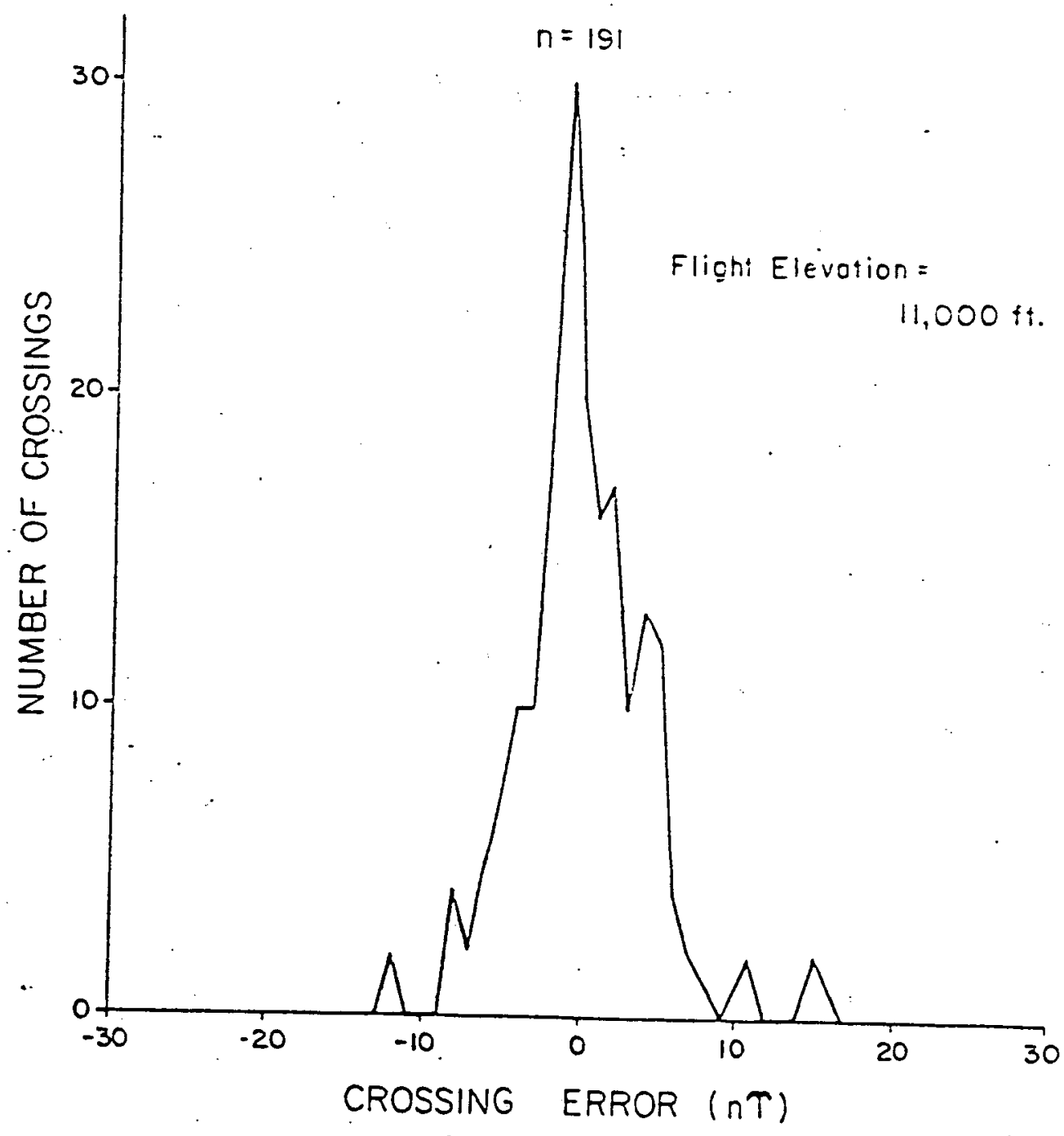

Figure 6.

Graph of 191 crossing errors calculated for the Lassen Peak 11,000-foot ASL deromagnetic survey. 


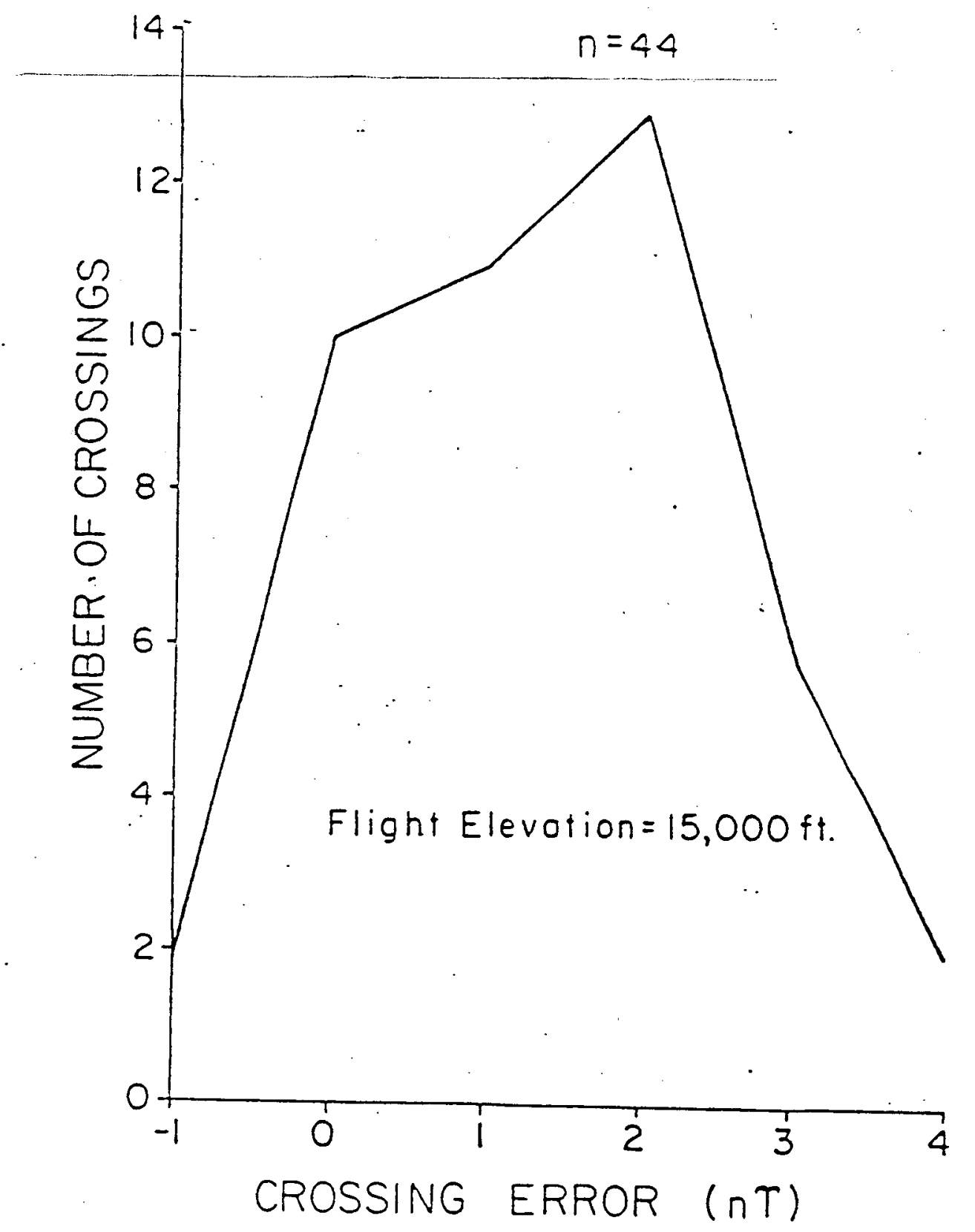

Figure 7 .

Graph of 44 crossing errors calculated for the Mt. Shasta 15,000-foot ASL aeromagnetic survey. 
Table 1. Northern California 9000 ft ASL survey' crossing error statistics.

Total Crossings

Mean

Median

Mode

RMS

RMS uncërtainty per line
2885

$$
\begin{aligned}
& 0 \mathrm{nT} \\
& -7 \mathrm{nT} \\
& -7 \mathrm{nT} \\
& 6.6 \mathrm{nT} \\
& 4.7 \mathrm{nT}
\end{aligned}
$$

Table 2. Notthern California 11,000 ft ASL survey crossing. error statistics.

Total Crossings

Mean

Median

Mode

RMS

RMS uncertainty per line
191

OnT

onT

$-i n T$

$5.7 \mathrm{nT}$

$4.0 \mathrm{nT}$ 
Table 3. Northern Cälifornia $15 p 00 \mathrm{ft}$ ASL survey crossing error statistics.

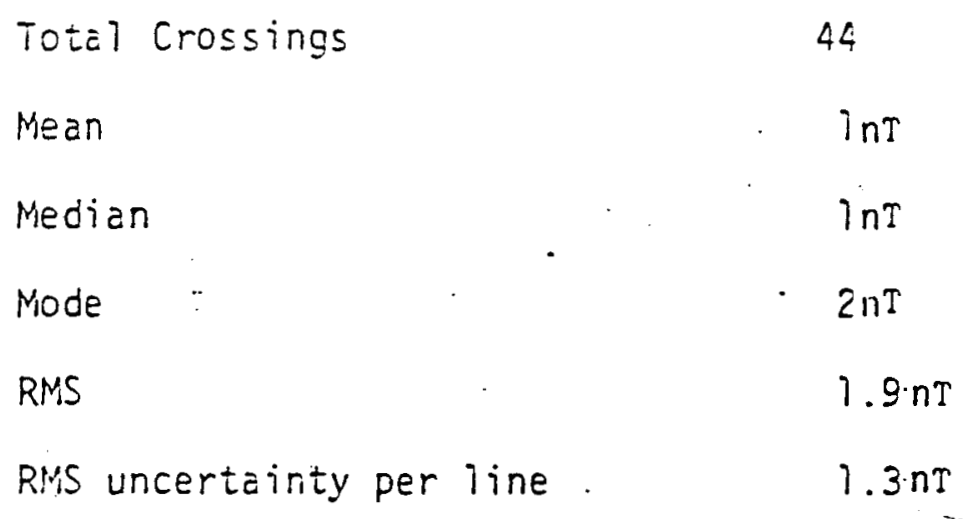




\section{Magnetic Anomelies of Horthern Célifornia}

Figure $\varepsilon$ shows a topographic map of the northern Califorria aeromagnetic survey area. "The contour interval is 1,000 feet and heâvy contours occur at 5,000 and 10,000 feet elevation. Mt. Shasta, 14,162

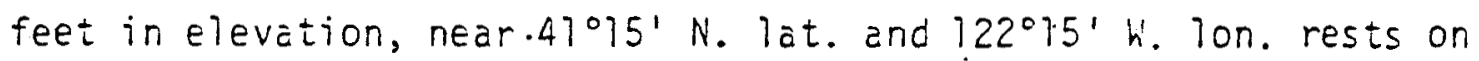
elevated terrane that extends east-northeastward and forms the Medicine Lake Highlands and northward towards the Oregon border along the axis of the Cascade Range. In the southwestern part of the survey area, the Sacramento River flows through Redding and into the north end of the Great Valley of Calitornia. Shasta Lake, between Redding and Mit. Shasta, occupies part of the dendritic drainage that flow's southwestward from the highlands about and north and east of Mt. Shasta. The axis of the Cascade Range strikes approximately south-southeast just east of Mt. Shastâ and through Lassen Pk. near $40^{\circ} 30^{\prime}$ N. lat. and $121^{\circ} 30^{\prime} \mathrm{K}$. long. The Modoc Plateau, with elevations generally between 4,000 and 5,000 feet, show's oniy relatively subdued relief with $\dot{\bar{a}}$ general northwest-soutriwest orientation (Macdonald, 1966).

- Paleozoic and Mesozoic sedimentary ano volcanic rocks, in places strongly metamorphosed, form the deeply dissected structures of the Klamath Mountain complex between Redding and Mt. Shasta in the western part of the survey area. Granitic rocks, mainly of Mesozoic age, intrude the older sedimentary and volcanic rocks. Cenozoic volcanic rocks that form the Modoc Plateau overlap the older Klamath Mountain rocks immediately north and east of Mt. Shasta and west of Lassen. Pk. Cenozoic continental sedimentary rocks and alluvial deposits of the

* Figures 8 and 9 are available at $1: 250,000$ scale in U.S. Geological Survey Open-File Report 82-198(Couch, 1982). 


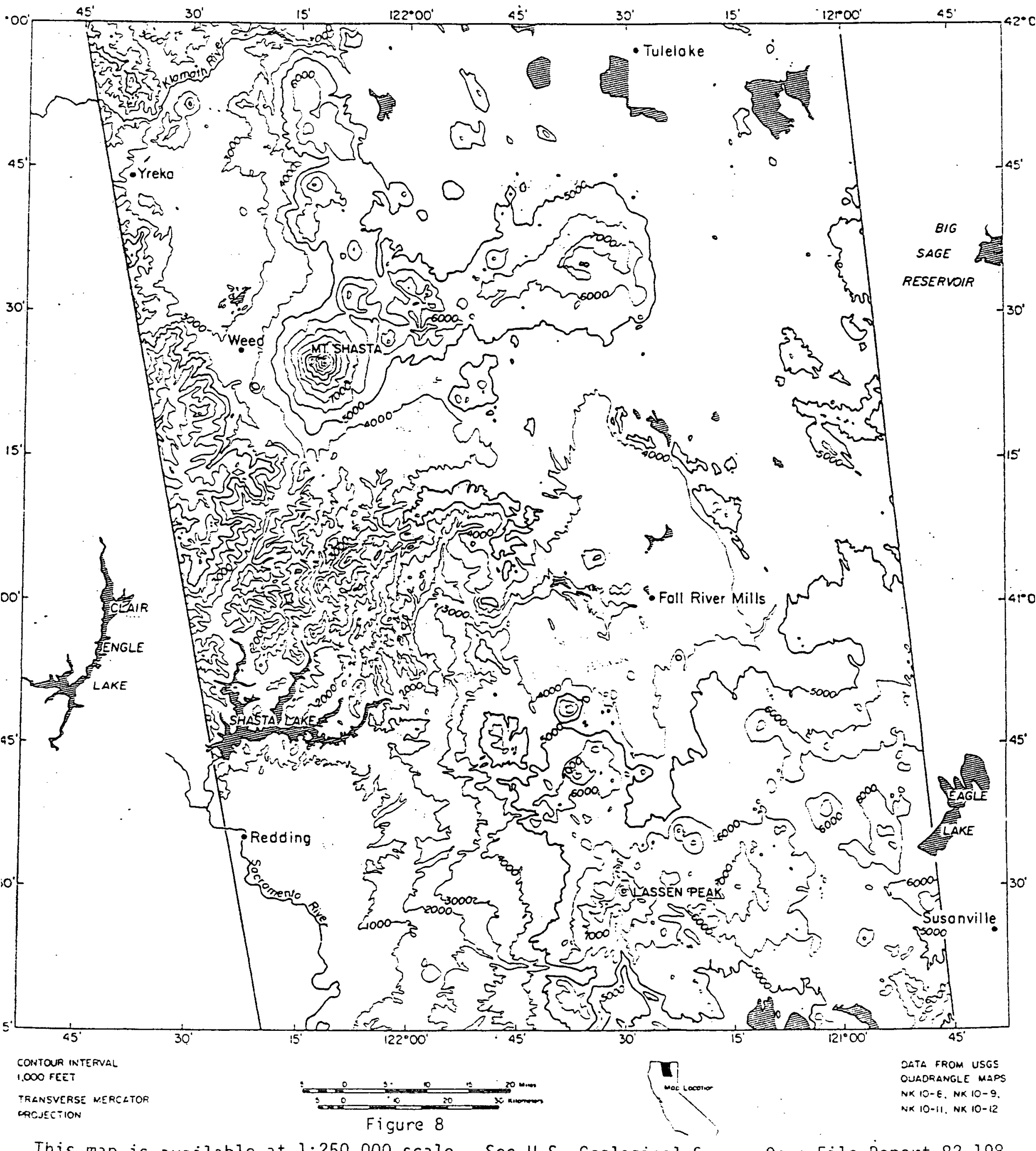

This map is available at 1:250,000 scale. See U.S. Geological Sfrvey Open-File Report 82-198 (Couch. 1982). 
Great-Valley overlap the Paieozoic and Mesozoic rocks of the klamath Complex south of Redding, California. 'The old rocks of the Klamath belt dip eastward beneath the Modoc Plateau and the Great-Valley and are. thought to extend northeastward into Oregon and southeasiward toward the Sierra Nevada (Irwin, 1966).

Figure 9 shows the total field magnetic-anomaly map of the northern California survey area. The contour interval is 100 nanoteslas, and heavy contours occur at $500 \mathrm{nT}$ intervals: Mt. Shasta and Lassen Pk. extend above the 9,000 -foot fr: int elevation of the map and generate "holes" in the map. Figure 10 shows the magnetic-anomaly map of Lassen Pk. and the area immediately about Lassen Pk. based on measurements made at a flight elevation of 11,000 feet. The contour interval is $50 \mathrm{nT}$, and heavy contours occur at $0, \pm 250 ;-500$ and, $-750 \mathrm{nT}$. Figure 17 show's the magnetic anomaly map of the Mt. Shasta area based on messurements at a flight elevation of $15,000_{\Lambda}$. The contour interval is $25 \mathrm{nT}$, and heavy contours occur at $0, \pm 125, \pm 250$; and $-375 \mathrm{nT}$.

Two prominent circular positive anomalies occur in the vicinity of Mt. Shasta. The westernmost positive anomaly, with an amplitude greater than $175 \mathrm{nT}$, occurs near the peak of Mt. Shasta whereas the easternmost positive anomaly, with an amplitude greater than $325 \mathrm{nT}$, occurs over a secondary cone near the base of Mt. Shasta on the east side (fig. 1). The amplitude of this anomaly at the 9,000-foot flight elevation, as shown in figure 9, is greater than 2,300 nT.

A marked negative anomaly of less than $800 \mathrm{nT}$, as observed at 9,000 feet elevation, occurs immediately northeast of the large - 


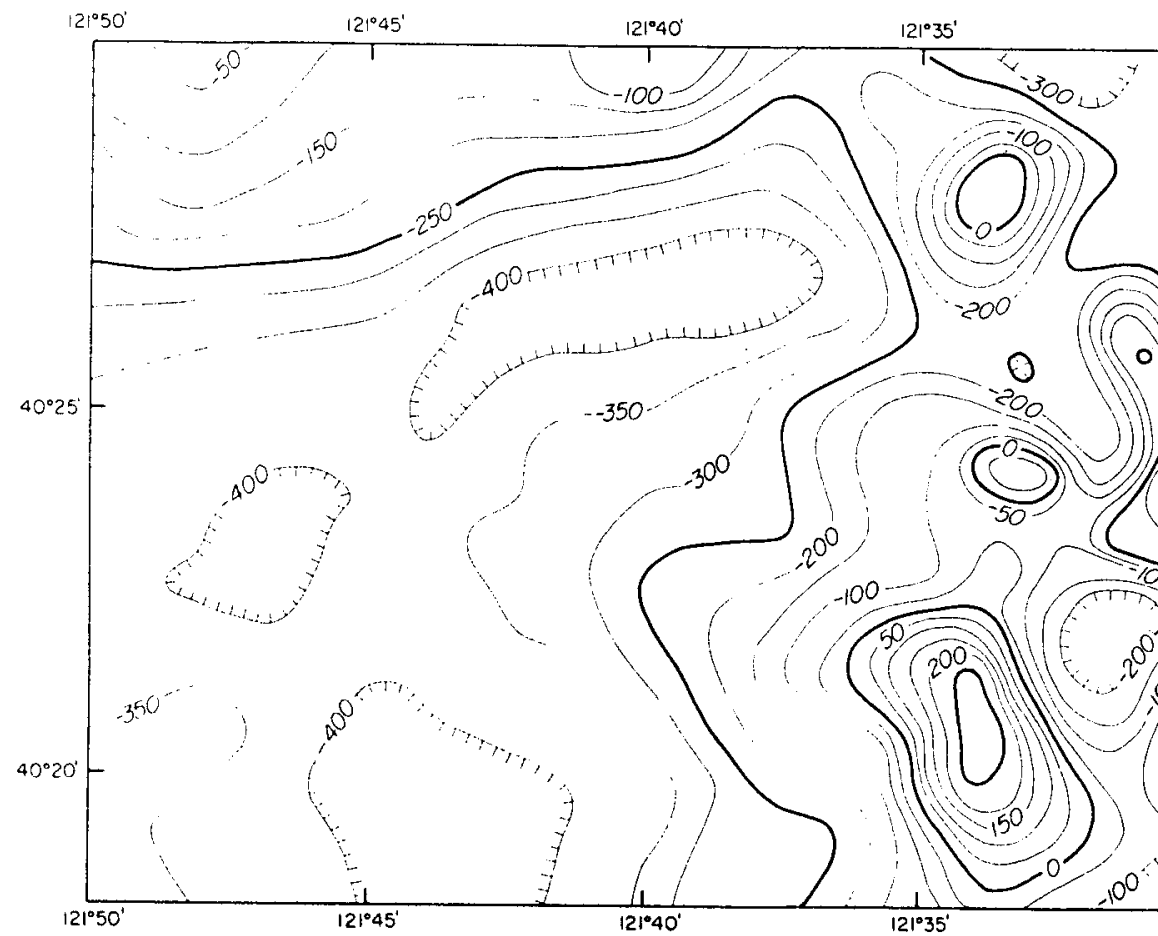

$121^{3} 30^{\circ}$
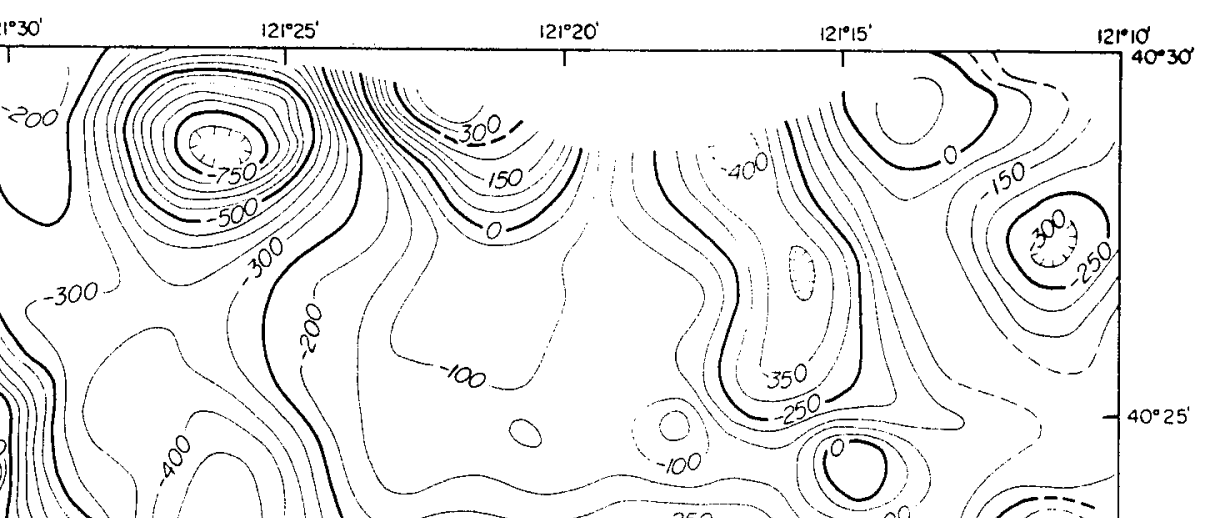

TOtAl FiEld AEROMAgnetic ANOMALY MAP

Contour intervol 50 nonotesias Estimated RMS uncertointy in measurements 4 nanoteslas

IGRF (1975), modified

Flight elevation 11,000 feet

Lassen Peak Area, Northern California

SCALE $1: 250,000$

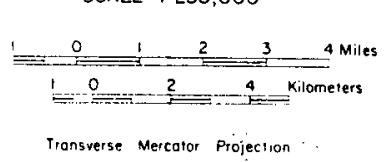

Figure 10. 


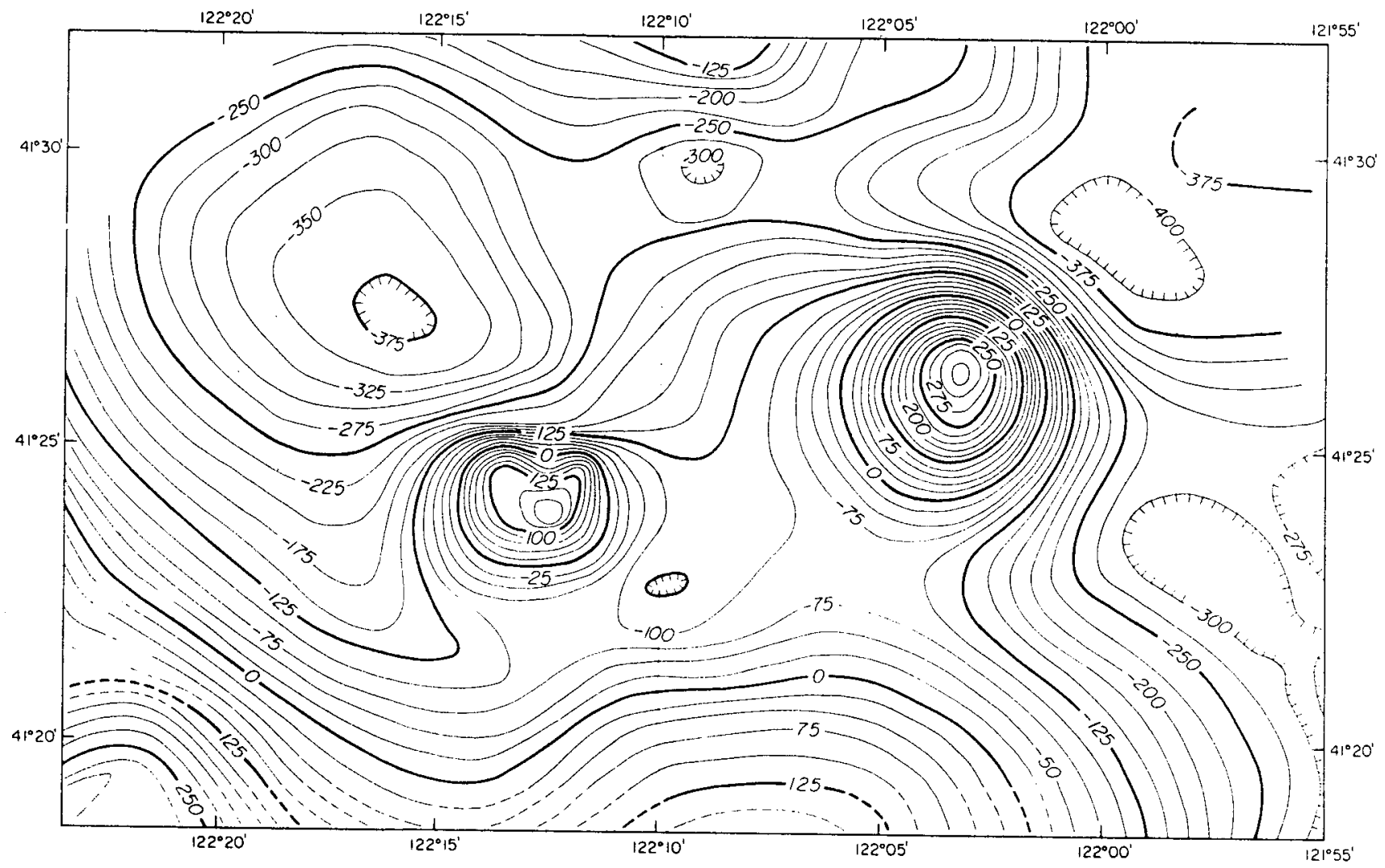

Contour interval 25 nanoteslas Estrimated RMS uncertointy in 1GRF (1975), modified

Total field aeromagnetic anomaly map Mount Shosto Area, Northern Colifornia

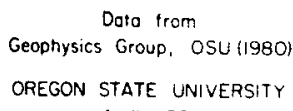

Flight elevation 15,000 te

$$
\begin{gathered}
\text { SCALE } 1: 250,000 \\
\text { Transverse Mercotor Projection }
\end{gathered}
$$

Figure 11. 
amplitude, nearly circular, positive. anomaly on the east side of Mt. Shasta. The positive anomialy shows a greater decrease in ampiitude than the negative anomaly when the flight elevation increases from 9,000 feet (figure 9 ) to 15,000 feet (figure 11); hence, the source of the negative anomaly is deeper than the source of the positive anomaly. If the anomaly pair is due to a dipole source body, the body is normally polarized and dips northeastward at less than $64^{c}$, the approximate dip of the Earth's dipole field in northern California. Aiternatively the anomalies reflect a positively polarized source body on top of a reversely polarized regional base.

A very broad, low-amplitude, negative magnetic anomaly located in the vicinity of Redding and the area east of Redding extends north toward Shasta Lake and then toward the northeast north of the lake. The anomaly generally coincides with the mipped Mesozoic sedimentary and volcanic rocks of the Klamath Mountain complex, and the long wavelength components of the anomaly appear to be present "beneatr" the short-wavelerigth components of the cascade Mouritains southeast of Mt. Shasta. The western edge of the negative anomály appears to delineate the eastward extent of the intrusive granitic and ultramafic rocks. of the Klamath Mountains.

Two lineaments are apparent in the magnetic-anomaly map of figure 9. One lineament strikes northwest from near $41^{\circ} 00^{\prime} \mathrm{N}$. lat., $120^{\circ} 45^{\prime}$ W. long to $42^{\circ} 00^{\prime} \mathrm{N}$. Tat., $122^{\circ} 00^{\prime} \mathrm{W}$. 1ong and separates the intermediate-wavelength magnetic anomalies of the northeastern Hodoc Plateau from the short-wavelength anomalies of the Cascade Range and southern Hodoc Plateau. The second lineament strikes northwest from near $40^{\circ} 15^{\prime} \mathrm{N}$. lat., $120^{\circ} 55^{\prime} \mathrm{W}$. long. toward Mit. Shasta. Both lineaments 
suggest changes or discontinuities in the basement structure. The southern lineation may be due to an extension of the Honey Lake Fault toward the northwest beneath the young volcanics of the Modoc Plateau. The magnetic anomalies also suggest several northeast-southwes.t lineations between Mt. Shasta and Mt. Lassen that may be related to trends of the Klamath Mountain Complex beneath the Cenozoic volcanics of the Cascade Range.

The Klamath Mountain Complex west of Mt. Shasta is a region of predominantly positive magnetic anomalies. The anomalies are large in amplitude and exceed 2,200 nT southwest of Mt. Shasta. The Mesozoic and Paleozoic age and degree of metamorphism of the rocks in this region suggest that a large part of the magnetic character of the rocks in this region is due to induced magnetization.

The Medicine Lake Highlands appear as an area of relatively low amplitude positive anomalies (with respect to the flight elevation above the volcanic rock) superimposed on a region of negative anomalies.

- The Cascade Mountain Range appears on the magnetic anomaly map of figure 9 as composed of numerous short-wavelength, high amplitude somewhat circular positive and negative anomalies. These small high. amplitude anomalies mark the locations of volcanic vents, intrusions and hyabyssal bodies of Tertiary to Recent age. The anomaly pattern of the Cascade Range appears diminished near $41^{\circ} \mathrm{N}$. latitude where the Klamath Hountain Complex and the northern extension of the Great Basin extend eastward. 


\section{References Cited}

Couch, R. W., 1982, Maps showing total-field aeromagnetic anomalies and topography of the Cascade Mountain Range, northern California, U.S. Geological Survey Open-File Report 82-198, scale 1:250,000.

Irwin, W. P., 1966, Geology of the Klamath Mountains Province. IN: Geology of Northern California. Ed. E. H. Bailey. California Div. of Mines and Geol. Bulletin 190, p. 19-38.

International Association of Geomagnetism and Aeronomy, 1976. International Geomagnetic Reference Field 1975. EOS, Trans. A. G. U. $57(3)$ : 120-121.

McLain, W., 1981. Geothermal and Structural Implicatiors of Magnetic Anomalies Observed Over the Southern Oregon Cascade Mountains and Adjoining Basin and Range Province. M.S. Thes is Oregon State University. $150 \mathrm{p}$.

Macdonald, G. A., 1966. Geology of the Cascade Range and Modoc Plateau. IN: Geology of Northern California. Ed. E. H. Bailey. California Div. of Mines and Geol. Bullet In 190, p. 65-96. 
$\lambda$ 